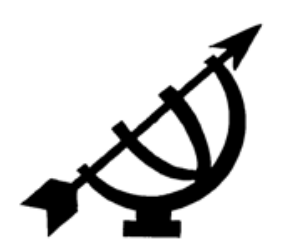

\title{
Towards authentic development
}

\author{
S. Fowler \\ Department of Management \& Commerce \\ University of Fort Hare \\ ALICE \\ E-mail: africa@amani.org.au
}

\section{Abstract \\ Towards authentic development}

This article explores the basis of the current definition of social development and deficiencies in this definition. In this context the power of today's global commercial empire is explored with well-documented evidence of the damage being done to human well-being in the interest of profit.

An alternative definition of development is proposed concluding with a profile of a developed society. It is suggested that, on the basis of the current definition, there is little hope of African countries ever becoming "developed". On the other hand, while there are still challenges to be faced, the proposed alternative profile offers a realistic possibility of being achieved.

\section{Opsomming}

\section{Op pad na egte ontwikkeling}

Hierdie artikel verken die onderbou van, sowel as die leemtes in 'n (tans) algemeen-aanvaarde definisie van sosiale ontwikkeling. Die mag van die hedendaagse kommersiële heerskappy word binne hierdie konteks opgevolg met goed-gedokumenteerde bewyse van die skade wat menslike welsyn berokken word in die belang van winsgewendheid.

'n Alternatiewe definisie van ontwikkeling word voorgestel met die profiel van 'n ontwikkelde gemeenskap as die slotsom. Die stelling word gemaak dat die huidige definisie van sosiale ontwikkeling min hoop bied vir Afrikalande om ooit "ontwikkeld" te wees. Terwyl daar nog uitdagings is om te oorkom, bied die voorgestelde alternatief 'n realistiese moontlikheid waarna gestreef kan word. 


\section{Introduction and personal prelude}

I first met B.J. (Bennie) van der Walt at the international conference held at Potchefstroom in 1975 where the International Association for the Promotion of Christian Higher Education (IAPCHE) was established. This was the beginning of a friendship that has endured every adversity to this day. He is one of my closest friends and most valued colleagues.

We have shared a passion for the people of Africa, supporting them in their endeavours to build effective social, political and educational structures for today's world with a critical eye; on the one hand critically retaining the good from traditional African cultures and on the other hand, critically selecting the good from Western cultures. I trust that what follows may be effective in taking a further step in this direction.

\section{The concept of development}

\subsection{History}

18 years ago, the Kenyan academic, B. Wanjala Kerre, in an article on the critical role of the development of science and technology in Africa, said the following (Kerre, 1992:376):

While Africa cannot isolate herself from the rest of modern civilization, it is quite obvious that modern cultural values which have been borrowed from the West can no longer promise humanity a balanced and humane lifestyle.

Instead, Kerre (1992:376) advocates, Africa ought to "take a leaf from her own past and forge an identity" based on moral, spiritual, intellectual, and social norms underpinned by traditional African values such as the importance of family, "individual and social responsibilities", "respect for human life", "love for children", and "sharing". He continues: "The good life in the African context will therefore be one where besides access to food, shelter, clothing, and medical care, the individual will have cultivated a balanced view of the self in his moral, spiritual and intellectual dimensions of life."

In so doing, he linked creativity in developing science and technology with a wide range of social values as essential to an authentic African development. After eighteen years, little has changed. Africans have become much greater users of technology, but have done little to create new technology; and they continue to replicate the cultural values of the West. 
There are no doubt a number of factors that contribute to this, but none more fundamental than the definition of development in relation to human societies. Currently the two major internationally recognised sources are the World Bank Development Report (World Bank, 2009) and the United Nations Development Report (United Nations Development Programme, 2009). For both of these, the key indicator of development is per capita financial wealth of the society shown by GDP and/or GNP.

The United Nations Human Development Report does provide a broader range of statistics but these remain quantifiable and do not significantly affect the development ranking. Thus the qualities of the good life identified by Kerre are ruled out by this definition of development. Even on this quantified definition of development it should be noted that the statistics show gross wealth and tell us nothing about the distribution of the wealth within the society.

\subsection{The global commercial empire}

For the first time in history today's world is dominated by a global commercial empire that promotes around the world a culture and lifestyle based on that of the "developed" societies. It is this cultural force that serves as the mainspring for the limited idea of development as quantifiable wealth. This empire uses all the power of today's technology, with its ability to generate eye-catching images for every form of mass media to promote their products as desirable. They are held out as the key to a good life. Unless people are very discriminating, or the product is not to their taste, buying the product becomes irresistible. Who does not want a good life?

Before long, this desire becomes a need; desire becomes a necessity. Clapp $(1998: 190,191)$ summarises very well:

... the consumer is schooled in insatiability. He or she is never to be satisfied, or at least not for long. The consumer is taught that persons consist basically of unmet needs that can be requited by commodified goods and experiences. Accordingly, the consumer should think first and foremost of himself or herself and meeting his or her felt needs. The consumer is taught to value above all else freedom, defined as a vast array of choices.

McKibben (1998:46) points out how the meaning of Christmas has been turned on its head by the values of this prevailing culture. Instead of celebrating the birth of "One who told us to give everything to the poor", we celebrate by "giving each other motorized tie racks". 
Perhaps the most damaging effect of this commercial empire is the education of people to be consumers and not producers. It promotes the idea that, if you can buy food ready to put in the microwave and onto the table, why go to all the trouble of making it yourself. This is not to say that this is never a useful thing to do, but when it becomes a pattern of life, it robs us of the joy of producing. This is not to say that this commercial empire brings us no good. To say that would be absurd. But if we become immersed in the cultural values of consumerism, as McKibben (1998:47) says, "we are being cheated of the truest happiness".

\subsection{The alliance of commerce and state}

Clapp (1998:1) adds another dimension to this cultural picture when he points out that two institutions have an unprecedented dominance in the shaping of public life - the space shared by all - in today's societies. These two institutions are the state and the market. In particular, it is the alliance between these institutions that enables the ever-increasing dominance of the global commercial empire and the inadequate model of development it promotes.

"Market" in this context means something very different from the place where people engage in buying and selling goods, such as that which characterised much of traditional Africa and still exists in many African towns. It refers to an institutionalised market consisting of an integrated network of commercial organisations dedicated to the creation of wealth by promoting increased consumption of their goods and services.

Lundin (1993:40, 41), following Philip Reith, refers to this culture as a therapeutic culture that promotes "the efforts of the autonomous self to discover fulfilment independent of the restraints of precedence and community". The central goal is to manipulate life's circumstances in order to achieve the individual's sense of wellbeing (Lundin, 1993:5, 6). In other words, in terms of Lundin's reference to Rorty (1991:201), it is a culture where the good life is one where the individual is able to manipulate the world "in order to get it to do what I want".

The State is allied with the commercial empire through its role in facilitating that empire's activities, all in the name of ensuring the country has a strong "economy". This has turned the original meaning of economy on its head. The original meaning was "the careful, or thrifty management of available resources". Today it means "the consumption of available resources" with the goal of 
ever-increasing consumption as "economic growth". The consequence is an ever-increasing depletion of resources.

\section{Quality of life and development in Western societies}

\subsection{Western societies}

A range of other sources indicates that financial wealth does not lead to the quality of life that we would expect of a society that has achieved a high level of development. One need only look to the escalating rate of suicides and obesity-related health problems that characterise modern Western societies to confirm this. Statistics provided by the American Foundation for the Prevention of Suicide (2007) claim that, in the past 45 years, "suicide rates have increased by 60 percent worldwide". What is more, the World Health Organisation reports (2006) that lifestyle factors have generated a global epidemic of health and life threatening obesity.

Additional evidence that points to the inadequacy of a quantitativelybased model of development is provided by the numerous surveys over recent years that have reported that being rich does not make people happy. In a recent US study of college graduates to track the relation between the attainment of goals and psychological health, the following conclusion was reached (Niemiec et al., 2009:306):

The relation of aspiration attainment to psychological health was found to differ as a function of the content of the goals. Attainment of the intrinsic aspirations for personal growth, close relationships, community involvement, and physical health related positively to basic psychological need satisfaction and psychological health. In contrast, attainment of extrinsic aspirations for money, fame, and image was unrelated to basic psychological need satisfaction and related slightly negatively to psychological health.

The above-mentioned evidence highlights the inadequacy of the use of quantitative data based on the financial wealth of a society as a benchmark of social development. A truly developed society will be one that offers its people a satisfying quality of life. As the philosopher, A.C. Grayling (2008), remarks: "The true equation between happiness and wealth is this: that happiness is wealth. Unlike wealth in the form of money and possessions, such happiness can never be quantified [...]". 


\subsection{The Iraq invasion}

The inadequacy of the quantitatively-based model of development is not only apparent when we look at quality of life in so-called developed nations, as indicated in the previous section, but also when we consider the application of this ideal of development to the still developing world. The Iraq invasion, which will be dealt with presently, and the treatment of the inhabitants of Diego Garcia effectively illustrate the deplorable consequences of pursuing development of this kind.

In January 2010, the Netherlands Commission of Inquiry into Iraq $(2010: 530,531)$ found that the military action of the US and Britain "had no sound mandate under international law". It also found that the political support of the Netherlands benefited the US by increasing global support for the actions of the US.

Meanwhile, in an ongoing inquiry on the same issue in Britain, Chapman (2010) reports:

Devastating evidence at the Iraq inquiry yesterday revealed that every senior legal adviser at the Foreign Office believed the conflict was in breach of international law. Sir Michael Wood, then the Foreign Office's senior legal adviser, warned ministers again and again that to go to war without approval from a UN Security Council resolution would constitute a 'crime of aggression' in international law.

Unlike the Dutch inquiry, which was a judicial inquiry headed by a senior judge, the British inquiry is not judicial. All the members are drawn from the Privy Council, an elite body which is generally composed of persons who are or have been prominent figures in the political world. Doward (2009) reports that Came Ross, the UK's former Iraq expert on the UN Security Council, fears that the inquiry

... would fail to establish a true account of how and why the UK opted to join the US in taking military action. [...] Ross says he believes the inquiry ... will produce little in the way of illumination because it suffers from 'an insidious intent' to establish that 'our democracy, parliament and government function as they should'.

The inquiry will be chaired by Sir John Chilcot, a former staff counsellor for the security and intelligence agencies who sat on the government's Butler inquiry into the use of intelligence in the buildup to the Iraqi war. "That Sir John Chilcot served on the Butler inquiry is like trying the same crime twice with the same judge and 
jury - not a credible standard for truth-seeking", Ross writes. He warns: "Many of those giving evidence will have a deep interest in confirming the government's narrative, for they are deeply implicated in having implemented it."

Doward (2009:2) also reports senior figures in the legal world in the UK as fearing that the inquiry "will do a job for the government". This, of course, is not to say that the Iraq regime was not repressive but only that the invading nations were violating international law by taking military action. Their action was comparable to that of an individual citizen who takes the law into his own hands by killing someone whom he suspects of murder. However, any international law is a lame duck since no law is effective unless there is power to enforce it. With the massive imbalance of power that characterises this world the most powerful nations will always be able to do what they like. This makes any "international law" an unjust law since it is effective only when applied to the weak.

\subsection{Stealing a nation}

The story of the forcible dispossession of the Chagossian, or Ilois people, by the US and Britain is perhaps the most damning evidence of the abuse of power in defiance of law and disregard for human rights of any of those that could be told. The story has been well told by John Pilger (2006) a noted investigative journalist who meticulously documents his reports by first-hand accounts. Noam Chomsky (2007:ii) describes his work as "a beacon of light in often dark times".

The Chagossians inhabited the small island of Diego Garcia in the Indian Ocean. Composed of African slaves and Indian indentured labourers, over the generations of their life on the island they blended into a single people with a distinctive single language - a variant of French Creole. They had housing, and employment with ample food and were planning to develop a tourist industry when their island was stolen from them and they became a displaced people on the far-off island of Mauritius, where they had only slum housing, no jobs and no cultural affinity with their new "home".

Why? For no reason other than the military interests of the US, the great power that presents itself as the champion of freedom and democracy. As Pilger (2006:40) puts it:

During the 1960s and 1970s British governments, both Labour and Tory, tricked and expelled the entire population of the 
Chagos, a British colonial dependency, so that their homeland could be given to a foreign power, the United States, as the site for a military base. This 'act of mass kidnapping' was carried out in high secrecy, along with the conspiracy that preceded it. For almost a decade, neither Parliament nor the US Congress knew anything about it, and no journalist revealed it. When the base had been established, a group of 'defence' correspondents were flown out by the Ministry of Defence and reported as expected, as if no-one had ever lived there; BBC news-readers still refer to US aircraft flying out to bomb Afghanistan and Iraq from the 'uninhabited' island of Diego Garcia.

Pilger interviewed a Chagossian woman, Lizette Talate, about her experience of these events. She had been in a film made by the British Colonial Office before these events took place showing the idyllic circumstances of the people in its colony on Diego Garcia. Pilger writes (2006:45-47):

'Maybe only the English can make a film that showed we were an established community, then deny their own evidence and invent the lie that we were transient workers. That's why they couldn't legally throw us out of our own homes; they had to terrify us into leaving or force us out.' 'How did they terrify you?' 'They tried to starve us. The food ships stopped arriving, and everything was scarce. There was no milk, no dairy products, no oil, no sugar, no salt. When they couldn't starve us out of our own homes, they spread rumours that we would be bombed, then they turned on our dogs.' The Chagossians love their dogs; they are inseparable ... 'At first they tried poisoned fish balls', said Lizette. 'That killed a few and left many in terrible agony. Then they paid a man to walk around with a big stick, beating them to death, or trying to.' 'What year was this?' 'Spring 1971. It was very hot. American soldiers had already begun to arrive to build the base. They backed several of their big vehicles against the brick shed where the coconuts were prepared; hundreds of dogs had been rounded up and imprisoned there. Then they gassed them through a tube from the truck's exhaust. You could hear them crying.'

Those who refused to leave were summoned to the Administrator's office and told they had no choice because their 'removal' was 'legal' under the rules of the new colony. This was a big lie. A senior judge, Lord Justice Sedley, noted years later that 'legal powers designed for the governance of the islands [were misused] for the illicit purpose of de-populating them'. The assembled people were told they would be loaded onto ships and deported. There is a photograph of this meeting. 
A white man wearing shorts and long socks is standing on the steps, addressing the crowd; children are looking up at the adults, who look stunned. Several appear to have dropped drown with shock; others seem stricken with grief. 'Magistrate Todd delivered the news,' said Lizette. 'There was a sort of hint that what they did to our dogs they were going to do to us. They were without pity.' Along with 180 others, Lizette and her family were forced onto the vessel, Nordvaer, which had plied between the Chagos and Mauritius and the Seychelles, transporting copra and taking supplies back to the islands.

The uneventful coming and going of this ship had helped give the Chagossians their best-known name, Illois, meaning 'islanders'. As a means of transporting this number of passengers across 2500 miles, it was hopelessly inadequate. They were allowed to take with them only minimal personal possessions; they had to leave behind their furniture, which they had bought with savings from their work in the plantations, and their precious chickens and ducks, donkeys and goats ... horses took pride of place on the deck of the Nordvaer. For five days, the horses were fed and the people were not. The men were herded onto the bridge and had to stand or crouch in very rough weather; the women and children were made to sleep in the hold on a cargo of fertiliser. People vomited and suffered diarrhoea; two women miscarried.

In 2007, 47 years later, (Carey, 2007:44-48) after a prolonged legal battle in the British courts, the Court of Appeal ruled unanimously that these events constituted a fundamental breach of human rights and deprivation of liberty with an order giving them the immediate right of the Chagossians to return to their homeland on Diego Garcia. This order was made effective immediately denying a request for a delay by the lawyers of the Government.

Despite this, might still prevails over law for those who are powerful enough - in this case it is the law of one nation and not international law. The US military base holds Diego Garcia and the people to whom it belongs by right of law remain in exile.

\section{Profile of a developed society}

As opposed to the dominant Western model of development which attaches minimal value to personal well-being, a model drawing from traditional African values would offer the advantage of creating room for considerations of this kind. Some of the key elements of such a model would be the provision of an authentic communal life and the affirmation of faith as a healing, enriching factor in human life. 
Whereas modern Western societies are essentially individualist, traditional African societies are strongly communal with a community being seen as a collective of individuals who join together for mutual benefit. Vincent Donovan, an American missionary who spent extended periods living with Masai communities in Tanzania, refutes the common misconception that African communal life suppresses individuality when he writes (Donovan, 1978:142):

When I came into contact with African communities for the first time, one of the things I noticed about them was the lack of competition within a community. No one really tried to stand out in a community, perhaps did not even want to [...] Everyone would point out the greatest athlete, or the best dancer and rested hopes on such gifted people to bring honour to the village or community [...].

Traditional African societies' ability to attach value to individuality without the accompanying burden of competitiveness enables the formation of lasting communal bonds. By comparison, Donovan (1978:141) writes: "The strange, changing, mobile, temporary disappearing communities of America can leave one without any experience of what community is". Not until he went to Africa, he asserts, did he come to know what a real community is.

In addition to offering more lasting communal bonds, African values are also conducive to the affirmation of faith's significance for human life. There is little doubt that humans do need to have faith in some source of meaning that transcends everyday life. There are those, indeed, who are content to be carried along with the current, but those who make a difference in the world identify the faith that gives enduring meaning to their lives. As Wentz (1987:13) aptly observes: "Because we are more than biology, more than physical function, we are open to the possibilities of understanding ultimate order and meaning for our existence. Humans are creatures who are not satisfied with function; they seek meaning."

This may be faith in one or another traditional religion, but it may also be faith in a secular source of meaning. We might think of the eminent Oxford mathematical physicist (Penrose, 1989:428) who finds the ultimate source of meaning in a Platonic world of ideas, at least in his mathematical activity, the area in which a large part of his work takes place. Or we could think of the philosopher, Richard Rorty, who sees culture as the source of ultimate meaning. He argues (Rorty, 1991:13-14): 
Our acculturation is what makes certain options live, or momentous, or forced, while leaving others dead, or trivial, or optional. We can only hope to transcend our acculturation if our culture contains (or, thanks to disruptions from outside or internal revolt, comes to contain) splits which supply toeholds for new initiatives. Without such splits - without tensions which make people listen to unfamiliar ideas in the hope of finding a means of overcoming those tensions - there is no such hope.

But, given the history of religions, which is all too often a history of social conflict, how can the affirmation of a faith in ultimate meaning, whether religious or secular, be a healing factor? The answer to that must be in mutual respect for the other's faith. And it can be an enriching factor if we are ready to listen to the faith of others. As a result we can learn to work together in harmony to build a better more life-enriching society.

Of importance is that we do not simply remain within the walls of our faith. Rather, we need to deliberately go out with confidence, identifying our faith and engaging in friendly interaction with those of other faiths. I deliberately say "interaction" rather than "dialogue" since we are often able to engage in verbal exchanges if we first interact by actions.

We should be the first to extend the hand of friendship, and neighbourly love, to those who are of another faith, or confess no faith at all. The one commandment by which we show the reality of our faith is "you shall love your neighbour as yourself. For you were called to freedom, brothers and sisters; only do not use your freedom as an opportunity for self-indulgence, but through love become slaves to one another" (Gal. 5:13-14).

It is only the path of the Samaritan that will enable us to bring spiritual light to the world's darkest corners. All our churches, Christian schools and universities, will bring no light unless they have wide open doors to interact with all our neighbours. In themselves they are good, even essential, to preserve the integrity of our faith. But if they become enclosed spaces and we do not regularly go out of these spaces to interact with those who do not share our faith, our light remains hidden under the "bushel basket". Indeed those who lead in all of these Christian institutions should encourage all within them to engage with the world around them.

Our Lord said: 
No one after lighting a lamp puts it under the bushel basket, but on the lampstand, and it gives light to all in the house. In the same way, let your light shine before others, so that they may see your good works and give glory to your Father in heaven. (Matt. 5:15, 16.)

Note that it is first of all the "good works" done in the Saviour's name that bring light to this world. In this way the Christian is called to action to assist in authentic social development. It is not good enough to say: "I am just one person without power so what's the use". If enough little people act they can make a difference in the larger picture.

\section{Conclusion}

This article suggests that the current practice of using quantitative measures of national wealth is inadequate as an indicator of social development. It fails to take into account the quality of life that a society provides for its people. Rather than trying to "catch up" with the "developed" societies of the West, African nations should pursue a more authentic model of development that focuses on personal well-being.

\section{List of references}

AMERICAN FOUNDATION FOR SUICIDE PREVENTION. 2007. International statistics. http://www.afsp.org Date of access: 19 Apr. 2010.

BARCLAY, L. 2010. Obesity linked to clear-cell renal cell carcinoma. British journal of urology international, 105:16-20.

CAREY, S. 2007. Diego garcia: "Time is very dear to us". New African, Jul. http:///www.exacteditions.com/exact/browse/432/532

CHAPMAN, J. 2010. Iraq war was a crime of aggression: the damning verdict of top Whitehall lawyers which No.10 refused to accept. Daily mail, 28 Jan. http://www.dailymail.co.uk/news/article-1246312/Chilcot-inquiry-Iraq-war-

The-damning-verdict-Whitehall-lawyers-invading-Iraq-ministers-refusedaccept. Date of access: 28 Jan. 2010.

CHOMSKY, N. 2002. Praise for John Pilger and Freedom next time. (In Pilger, J. Freedom next time: resisting the empire. New York: Nation Books, p. ii.)

CLAPP, R., ed. 1998. The consuming passion. Downers Grove: InterVarsity.

DONOVAN, V.J. 1978. Christianity rediscovered. Maryknoll: Orbis.

DOWARD, J. 2009. Sir John Chilcot "wrong man to head Iraq invasion inquiry". The Guardian, 15 Nov. http://www.guardian.co.uk/world/2009/nov/15/sirjohn-chilcot-wrong-man Date of access: 28 Jan. 2001.

GRAYLING, A.C. 2008. Have-a-go deaths are never a waste. http://www. telegraph.co.uk/comment/3557112/happiness-is-the-measure-of-truewealth.html\#postComment Date of access: 15 Apr. 2010. 
KERRE, B.W. 1992. Science and technology: critical tools in the battle for the second scramble for Africa. (In Ndeti, K. \& Gray, K.R., eds. The second scramble for Africa. Nairobi: Professors World Peace Academy - Kenya. p. 369-382.)

LUNDIN, R. 1993. The culture of interpretation. Grand Rapids: Eerdmans.

MCKIBBEN, B. 1998. Returning God to the centre: consumerism and the environmental threat. (In Rodney C., ed. The consuming passion: Christianity and the consumer culture. Downers Grove: InterVarsity. p. 4050.)

NETHERLANDS COMMISSION OF INQUIRY INTO IRAQ. 2010. Conclusions. http://www.onderzoekscommissie-irak.nl Date of access: 27 Jan. 2010.

NIEMIEC, C.P., RYAN, R.M. \& DECI, E.L. 2009. The path taken: consequences of attaining intrinsic and extrinsic aspirations in post-college life. Journal of research in personality, 43:291-306.

PENROSE, R. 1989. The emperor's new mind. New York: Oxford University Press.

PILGER, J. 2006. Freedom next time: resisting the empire. London: Transworld.

RORTY, R. 1991. Objectivity, relativism and truth. Cambridge: Cambridge University Press.

UNITED NATIONS DEVELOPMENT PROGRAMME. 2009. Human development report. New York: Palgrave Macmillan.

WENTZ, R.E. 1987. Why do people do bad things in the name of religion? Macon: Mercer University Press.

WORLD BANK. 2009. World development report 2010: statistical annexes. Washington: World Bank.

WORLD HEALTH ORGANIZATION. 2006. Obesity and overweight. Fact sheet no. 311. http://www.who.int.mediacentre/factsheets/fs311/en/index.html Date of access: 19 Apr. 2010.

\section{Key concepts:}

authentic development

commercial empire

development

psychological well-being

social harmony

\section{Kernbegrippe:}

egte ontwikkeling

kommersiële ryk

ontwikkeling

psigologiese welstand

sosiale harmonie 
